\title{
Description of Thermus thermophilus (Yoshida and Oshima) comb. nov., a Nonsporulating Thermophilic Bacterium from a Japanese Thermal Spa
}

\author{
TAIRO OSHIMA ${ }^{1}$ and KAZUTOMO IMAHORI \\ Department of Agricultural Chemistry, Faculty of Agriculture, University of Tokyo, Tokyo, Japan
}

\begin{abstract}
The properties of an extremely thermophilic bacterium isolated from water at a Japanese hot spring and previously named Flavobacterium thermophilum are described. The cells are gram-negative, nonsporulating, aerobic rods containing yellow pigment. The optimum temperature for growth is between 65 and $72 \mathrm{C}$, the maximum being $85 \mathrm{C}$ and the minimum being $47 \mathrm{C}$. The guanine plus cytosine content of the deoxyribonucleic acid of the thermophile is $69 \mathrm{~mol} \%$. This microorganism is sensitive to various antibiotics including those which are known to be rather ineffective against gram-negative bacteria. Spheroplast-like bodies are formed upon treating intact cells with egg-white lysozyme at $60 \mathrm{C}$. The spheres are osmotically more stable than mesophile protoplasts, and their rupture under hypotonic conditions is not complete unless $0.5 \%$ Brij 58 is added to the suspension. Bulk protein extracted from this thermophile is much more stable to heat than mesophile proteins, and only about $10 \%$ of the total protein is denatured by heating at $110 \mathrm{C}$ for $5 \mathrm{~min}$. Nevertheless, the amino acid composition of the bulk protein is similar to that of mesophile proteins. As the properties of this organism are similar to those of Thermus aquaticus (Brock and Freeze) and inasmuch as Flavobacterium is a poorly defined genus, this thermophilic microorganism is transferred to the genus Thermus as $T$. thermophilus (Yoshida and Oshima) comb. nov. The type strain is HB8 (=ATCC 27634).
\end{abstract}

For many years thermophilic organisms have been of general biological interest, and thermophilic bacteria have been isolated from a wide variety of sources, such as compost, sewage, soil, and water. The ability of thermophiles to grow at temperatures that denature enzymes, nucleic acids, and cellular organelles of mesophiles has been intensively studied in the past few years, and much is now known about the growth of thermophilic microorganisms and the biochemical properties of their cellular components. Heretofore, studies on thermophilic bacteria have mainly been on spore formers of the genus Bacillus, and especially on B. stearothermophilus, which is a moderate thermophile having a maximum temperature for growth of 75 to $70 \mathrm{C}$

Recently, Brock and Freeze (5) isolated from water at a hot spring in the United States an extremely thermophilic bacterium which they named Thermus aquaticus. T. aquaticus is a nonsporulating bacterium having a maximum

'Present address: Mitsubishi-Kasei Institute of Life Sciences, Minamiooya, Machida, Tokyo 194, Japan. temperature for growth of $79 \mathrm{C}$. We have isolated nonsporulating, thermophilic bacteria from hot springs in Japan. Among those isolated, one strain is capable of growing at over $80 \mathrm{C}$. Although a variety of bacteria has been found in thermal springs in Japan (7), this isolate has not been reported previously by other authors. In the previous studies involving this organism $(15,22-25)$, it was tentatively placed in the genus Flavobacterium. The results of an investigation to determine the proper taxonomic niche of this organism and to attempt to gain some understanding of the molecular basis of thermophily are reported here.

\section{MATERIALS AND METHODS}

Bacterial strain. The strain studied here (HB8) was isolated on 23 September 1968, from a hot spring ( 80 $\mathrm{C}, \mathrm{pH}$ 6.3) at Mine, Shizuoka Prefecture, Japan. It has been deposited at the Fermentation Research Institute, Agency of Industrial Science and Technology, Chiba, Japan, under the number 2074 and at the American Type Culture Collection (ATCC), Rockville, 
Md., under the number 27634 . This strain has been maintained by the authors in a freeze-dried state for at least 30 months at $-18 \mathrm{C}$ and under reduced pressure and on an agar slant for 5 weeks in a refrigerator.

Culture media. The medium used for the cultivation of strain HB8 consisted of $0.8 \%$ polypeptone (Daigoeiyo Chemical Co. Ltd., Osaka, Japan), $0.4 \%$ yeast extract (Kyokuto Seiyaku Co. Ltd., Tokyo, Japan), and $0.3 \%$ sodium chloride in distilled water. In some experiments, polypeptone was replaced by $0.6 \%$ Casamino Acids (Kyokuto Seiyaku Co. Ltd.). The medium was adjusted to $\mathrm{pH} 7.5$ (measured at room temperature using Toyo pH test paper no. 20) by adding $1.0 \mathrm{~N}$ sodium hydroxide solution. The temperature-dependent coefficient of the medium was estimated to be $-0.01 \mathrm{pH}$ unit per degree. Unless otherwise noted, cultures were incubated at $75 \mathrm{C}$ in a dry oven. When necessary, sterile distilled water was added to the medium at suitable intervals to replace the water lost by evaporation. Agar plates were prepared by adding powdered agar (final concentration, 2\%, Wako Pure Chemical Industries, Ltd., Osaka, Japan) to the poly peptone-yeast extract medium. The agar plates were incubated at $60 \mathrm{C}$.

The medium used for the gelatin liquefaction test was prepared by dissolving $300 \mathrm{~g}$ of gelatin (Junsei Pure Chemicals Co. Ltd., Tokyo, Japan) in $100 \mathrm{ml}$ of the Casamino Acids-yeast extract medium. After inoculation, tubes containing the gelatin medium were incubated at $75 \mathrm{C}$ for 2 weeks. Every 2 days, water was added to replace that lost during the incubation period. One tube was not inoculated and served as a control. Liquefaction of gelatin was judged by observing solidification of the medium after cooling in an ice bath for $20 \mathrm{~min}$.

Cell growth. Bacterial growth was followed by measuring the absorption of the culture at $600 \mathrm{~nm}$ using a spectrophotometer (Model QU-3, Ito Electro Medical Instruments Mfg. Co. Ltd., Tokyo, Japan). A linear relation between the cell concentration and the absorbancy was observed in the range of absorbancy of 0.1 to 0.6 . By counting the cell population with a hematometer, it was estimated that 1.0 unit of absorbancy at $600 \mathrm{~nm}$ corresponded to $2.1 \times 10^{8}$ cells per $\mathrm{ml}$. The results are in fairly good accord with those obtained by counting viable cells on agar plates.

Cell-free extract. For large-scale cultivation, cells were grown in polystyrene bottles containing 3 liters of the polypeptone-yeast extract medium in an oven at $75 \mathrm{C}$. The medium was aerated during the incubation at a rate of 1 liter $/ \mathrm{min}$ through a glass-filter ball. Usually it was not necessary to sterilize the medium. A few drops of octyl alcohol were added to prevent foaming.

Harvested cells ( $10 \mathrm{~g}$ wet weight) were suspended in $20 \mathrm{ml}$ of $0.05 \mathrm{M}$ tris(hydroxymethyl)aminomethane (Tris)-hydrochloride buffer, $\mathrm{pH} 7.5$, and subjected to sonic oscillation $(10 \mathrm{kHz}, 100 \mathrm{~W}$ for $10 \mathrm{~min}$ using a Toyo Riko UD-N-50-6 sonic oscillator). The homogenate was centrifuged at $10,500 \times g$ for $20 \mathrm{~min}$ to remove cell debris. The protein concentration of the supernatant was estimated to be $30 \mathrm{mg} / \mathrm{ml}$ using Kalckar's equation (10).

Antibiotics. Gramicidin J and chloramphenicol were products of the Sigma Chemical Co., St. Louis, Mo.
Streptomycin and penicillin $G$ were purchased from Banyu Pharmaceutical Co. Ltd., Tokyo, Japan. Methicillin and tetracycline were from the Meiji Seika Co. Ltd., Yokohama, Japan, and Japan Lederle, Ltd., Saitama, respectively. Ristocetin, ampicillin, D-cycloserine, and novobiocin were provided by $\mathrm{H}$. Matsuzawa in our laboratory, and actinomycin D was kindly given by $M$. Kageyama, Mitsubishi-Kasei Institute of Life Sciences.

The effects of various inhibitors were studied by observing growth in liquid media containing inhibitors. A drop of inoculum obtained from a culture grown overnight in the standard polypeptone-yeast extract medium was transferred into polypeptone-yeast extract medium containing a suitable amount of an antibiotic or antibacterial agent. The medium was then incubated in an oven at $75 \mathrm{C}$ for $48 \mathrm{~h}$.

Chemical analysis of DNA. Deoxyribonucleic acid (DNA) was extracted by the method of Saito and Miura (16) and further purified by isopropanol fractionation (12). The nucleic acid preparation was hydrolyzed by treatment with $60 \%$ perchloric acid in a boiling water bath for $60 \mathrm{~min}$ (13). Paper chromatography of the hydrolysate was carried out by. ascending development on paper strips $(2$ by $40 \mathrm{~cm}$ ) (Toyo Roshi No51A). The solvent systems used were methanol-12 N HCl-water $(7: 2: 1, \mathrm{vol} / \mathrm{vol})$ and isopropanol $(6.5 \mathrm{ml})-12 \mathrm{~N} \mathrm{HCl}(1.67 \mathrm{ml})$-water (final volume, $10 \mathrm{ml}$ ) (22). The spots were cut out and eluted by soaking in $0.1 \mathrm{~N} \mathrm{HCl}$. The nucleotide bases thus eluted were determined by their ultraviolet absorption spectra using the molar extinction coefficients recorded in the literature (22). A Beckman DK-IIA ratio recording spectrophotometer (Fullerton, Calif.) was used in the spectrophotometric determinations.

Amino acid analysis of the bulk protein. The bulk protein of the thermophile in the cell-free extract was $S$-carboxymethylated as described by Crestfield et al. (6) but with a slight modification. To $20 \mathrm{ml}$ of the extract, $4 \mathrm{ml}$ of $0.1 \mathrm{M}$ sodium ethylenediaminetetraacetate, $36.1 \mathrm{~g}$ of urea, and $1.0 \mathrm{ml}$ of $\beta$-mercaptoethanol were added. The mixture was diluted to 75 ml, adjusted to $\mathrm{pH} 7.8$, and incubated at $70 \mathrm{C}$ for $1 \mathrm{~h}$. No nitrogen barrier was used during the incubation. Carboxymethylation was carried out by adding a solution of monoiodoacetic acid $(2.7 \mathrm{~g}$, Merck and Co. Inc., in $10 \mathrm{ml}$ of $1.0 \mathrm{M}$ sodium hydroxide) to the mixture. After standing for $30 \mathrm{~min}$ in the dark, the reaction mixture was dialyzed against distilled water and then freeze-dried. The $S$-carboxymethylated protein thus obtained was dissolved in $6 \mathrm{~N}$ hydrochloric acid (about $2 \mathrm{mg} / \mathrm{ml}$ ) and then hydrolyzed by incubation at $105 \mathrm{C}$ for $24 \mathrm{~h}$. The amino acid content of the hydrolysate was analyzed using a Shibata amino acid analyzer, model AA-600 (Shibata Seisakusho, Tokyo, Japan). The same procedure was applied to a cell-free extract of Escherichia coli.

Thermal stability of bulk protein. Heat stability of the bulk protein of the thermophile in the cell-free extract was investigated by estimating the amount of protein precipitated by heating. An extract obtained by sonic treatment was diluted to a suitable protein concentration with $0.05 \mathrm{M}$ Tris-hydrochloride buffer, $\mathrm{pH}$ 7.5. Samples $(1.0 \mathrm{ml}$ each) of the diluted extract 
were heated at various temperatures for $5 \mathrm{~min}$ in test tubes $(1 \mathrm{~cm}$ diameter) without caps, and then rapidly cooled in an ice bath. The precipitate of denatured protein was collected by centrifugation at $1,000 \times g$ for $30 \mathrm{~min}$, disssolved in $2 \%$ sodium carbonate containing $0.4 \%$ sodium hydroxide, and determined by the method of Lowry et al. (11). Total protein in the extract was precipitated by addition of an equal volume of $10 \%$ perchloric acid containing $0.3 \%$ uranyl acetate. The precipitate was collected and estimated as described. The denatured protein was calculated as a percentage of the total amount of protein precipitated.

\section{RESULTS}

Isolation. Samples (about $2.0 \mathrm{ml}$ per tube) of water from the thermal spring were mixed with a solution containing yeast extract, polypeptone, and sodium chloride (final concentrations: $0.4,0.8$, and $0.3 \%$, respectively; $\mathrm{pH} 7.0$ at room temperature) in test tubes covered with loosely fitting aluminum caps. The tubes were placed in an incubator at $75 \mathrm{C}$ without shaking. Sterile water was added to the tubes at intervals to compensate for that lost by evaporation. After a few days, turbidity and pellicles were seen in the medium, indicating bacterial growth. A drop of the turbid medium was transferred into $5 \mathrm{ml}$ of fresh medium and incubated at $75 \mathrm{C}$ for a few days.

Similar transfers were made three more times, and then single colonies were isolated by streaking samples of the enrichments on agar plates. One of the thermophilic colonies isolated was studied in detail. To insure that the isolate was pure, it was again streaked on an agar plate.

Using this same method, thermophilic rods similar to those of strain HB8 have been isolated from thermal waters of other hot springs in Japan. They were also gram negative and nonsporeforming and contained a yellow pigment. This suggests that this thermophile and/or closely related species is widely distributed in waters of hot springs in Japan.

Microscope observations. Cells of strain HB8 are long rods (Fig. 1 and 2) with average dimensions of $0.5 \mu \mathrm{m}$ by $3.0 \mu \mathrm{m}$. No spores have been observed either by phase-contrast or electron microscopy. Cells grew singly, in pairs, and sometimes in chains in the polypeptoneyeast extract medium at $75 \mathrm{C} \mathrm{(Fig.} \mathrm{1).} \mathrm{The} \mathrm{cells}$ were gram negative, and no motility was

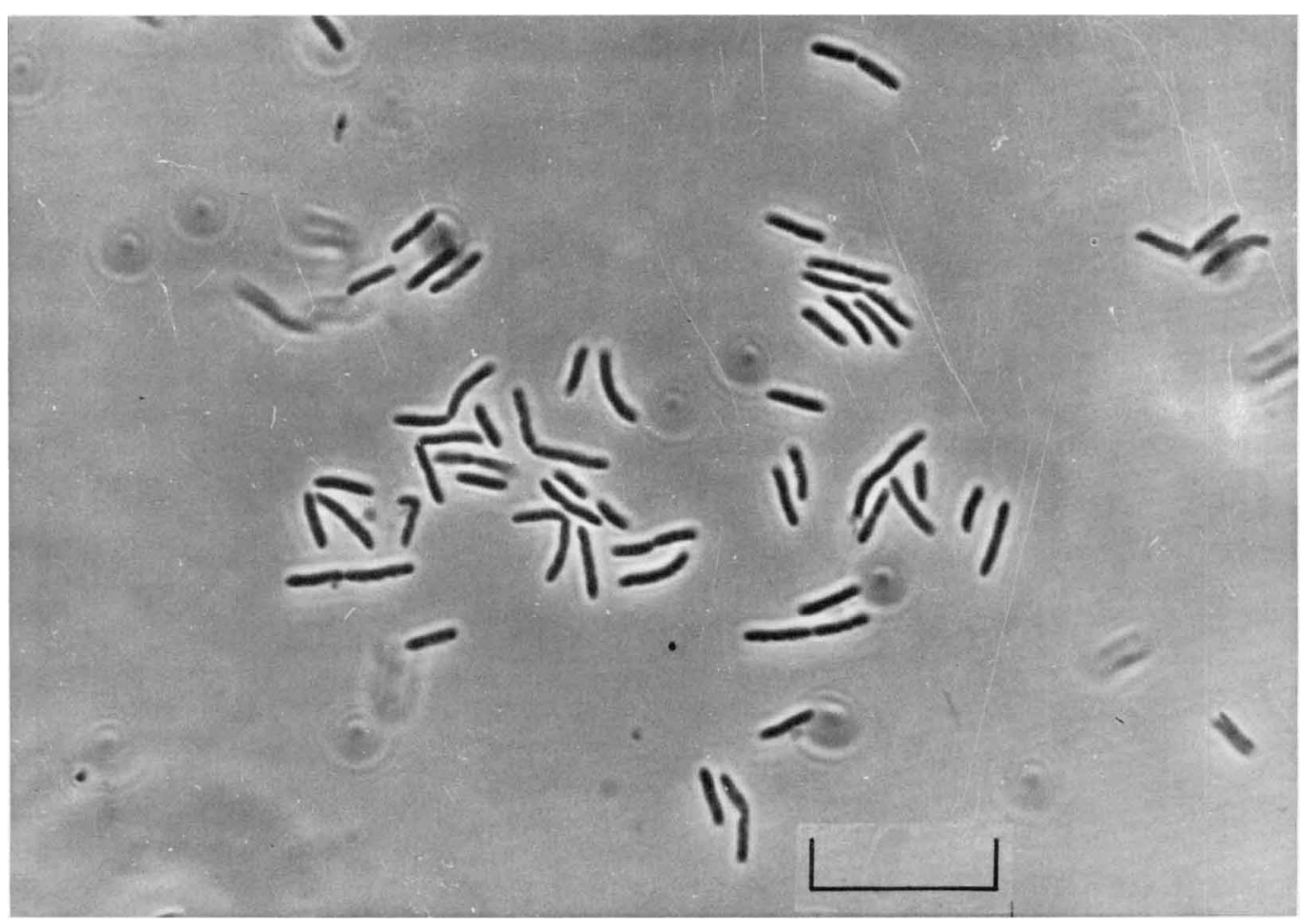

FIG. 1. Appearance of cells of strain HB8. The cells were grown in polypeptone-yeast extract medium at $75 C$ without shaking. The picture was taken using an Olympus phase-contrast microscope, model $S$-Ke-II. Magnification $\times 1,000$. The bar indicates $10 \mu \mathrm{m}$. 


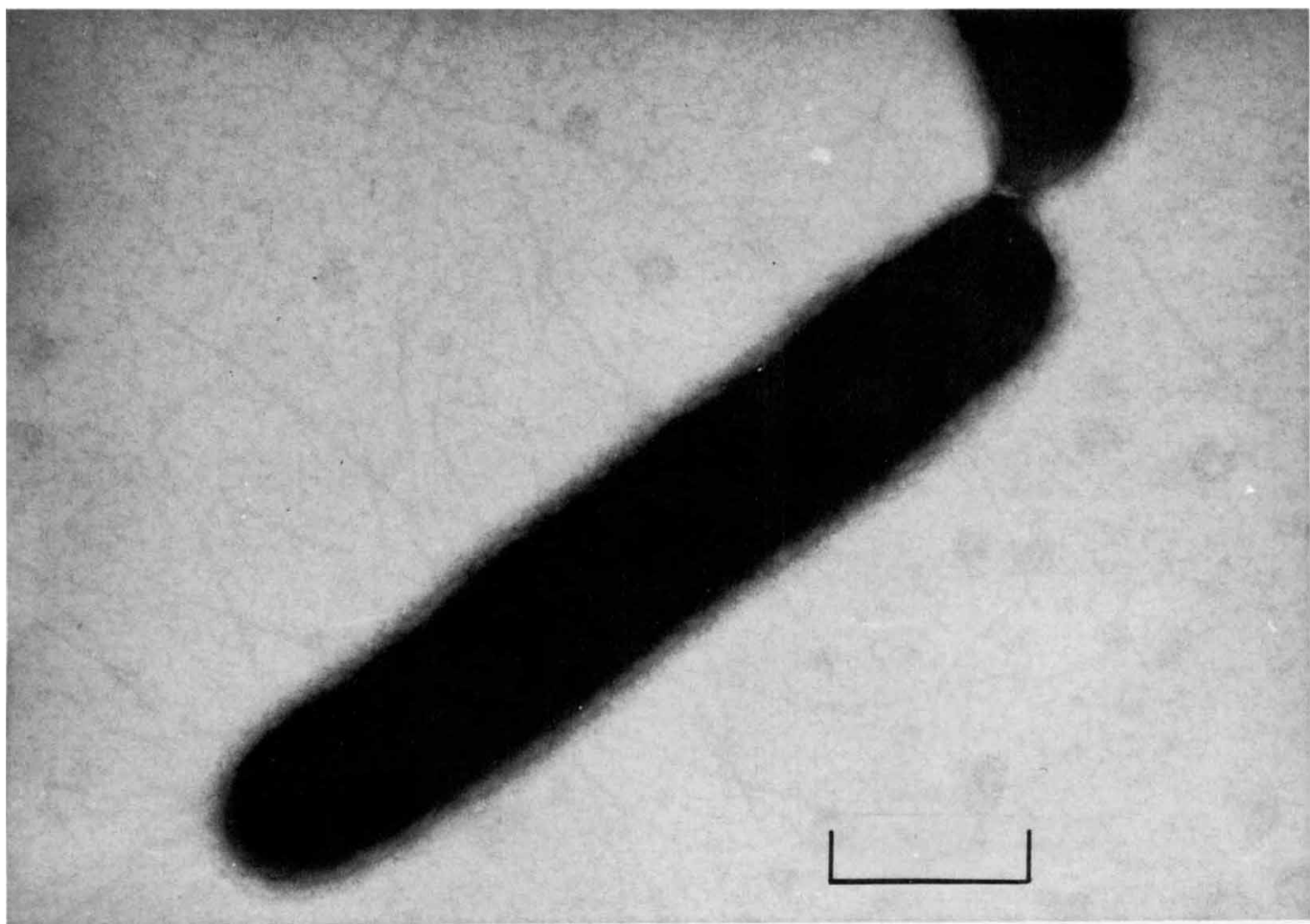

FIG. 2. Electron micrograph of strain $H B 8$ cells. The picture was taken using an electron microscope, Japan Electron Optics Laboratory, model $7 A$, at a magnification of $\times 27,500$. The bar indicates $0.5 \mu \mathrm{m}$.

observed by phase-contrast microscopy at room temperature.

A preliminary investigation was carried out on the ultrastructure of cells of strain HB8. An electron micrograph of an ultrathin section (Fig. 3) shows that the cell envelope contains structural features (namely three layers) similar to those of other gram-negative bacteria. Figure 3 also shows intracytoplasmic membrane systems which are probably vesicular mesosomal configurations that often contain electrondense particles. More detailed studies on the ultrastructure of this strain will be reported elsewhere by A. Matsuda and his co-workers.

Pigments. The yellow pigments produced by strain HB8 were not soluble in the medium used. Packed cells harvested from the polypeptone-yeast extract medium after growth at $75 \mathrm{C}$ appeared yellowish orange. The pigments were extracted by suspending the cell paste in $90 \%$ acetone. The absorption spectrum of the extract had a peak at $453 \mathrm{~nm}$ with shoulders at $473 \mathrm{~nm}$ and $430 \mathrm{~nm}$ (Fig. 4). This spectrum suggests that the extract contained a carotenoid compound(s).

Cultural characteristics. The organism is strictly aerobic. Growth was observed only on the surface of a soft agar stab. A pellicle and/or flocculent sediment often developed when the thermophile was grown in a liquid medium without shaking. Colonies on agar plates were round (about $1 \mathrm{~mm}$ in diameter after $24 \mathrm{~h}$ of incubation at $60 \mathrm{C}$ ) with a smooth, flat surface and a yellowish-orange color.

Acid but no gas was produced fairly quickly from glucose and galactose and slowly from maltose and lactose. No acid was produced from sucrose or mannitol. The cells reduced litmus slowly at $75 \mathrm{C}$ and slowly liquefied gelatin. They did not form indole from polypeptone or reduce nitrate.

At room temperature the optimum $\mathrm{pH}$ for growth of this strain was around 7.5; therefore it would be roughly $\mathrm{pH} 7.0$ at $75 \mathrm{C}$, since the temperature-dependent coefficient of the medium is $-0.01 \mathrm{pH}$ unit per degree. No growth was observed in media below pH 5.1 or over $\mathrm{pH}$ 9.6. In these experiments, $\mathrm{pH}$ values were measured at room temperature using a Hitachi-Horiba F-5 pH meter (Kyoto, Japan). The optimum concentration of sodium chloride for growth in polypeptone-yeast extract medium was determined to be about 0.2 to $0.3 \%$. Growth was poor in the presence of $2 \%$ sodium 


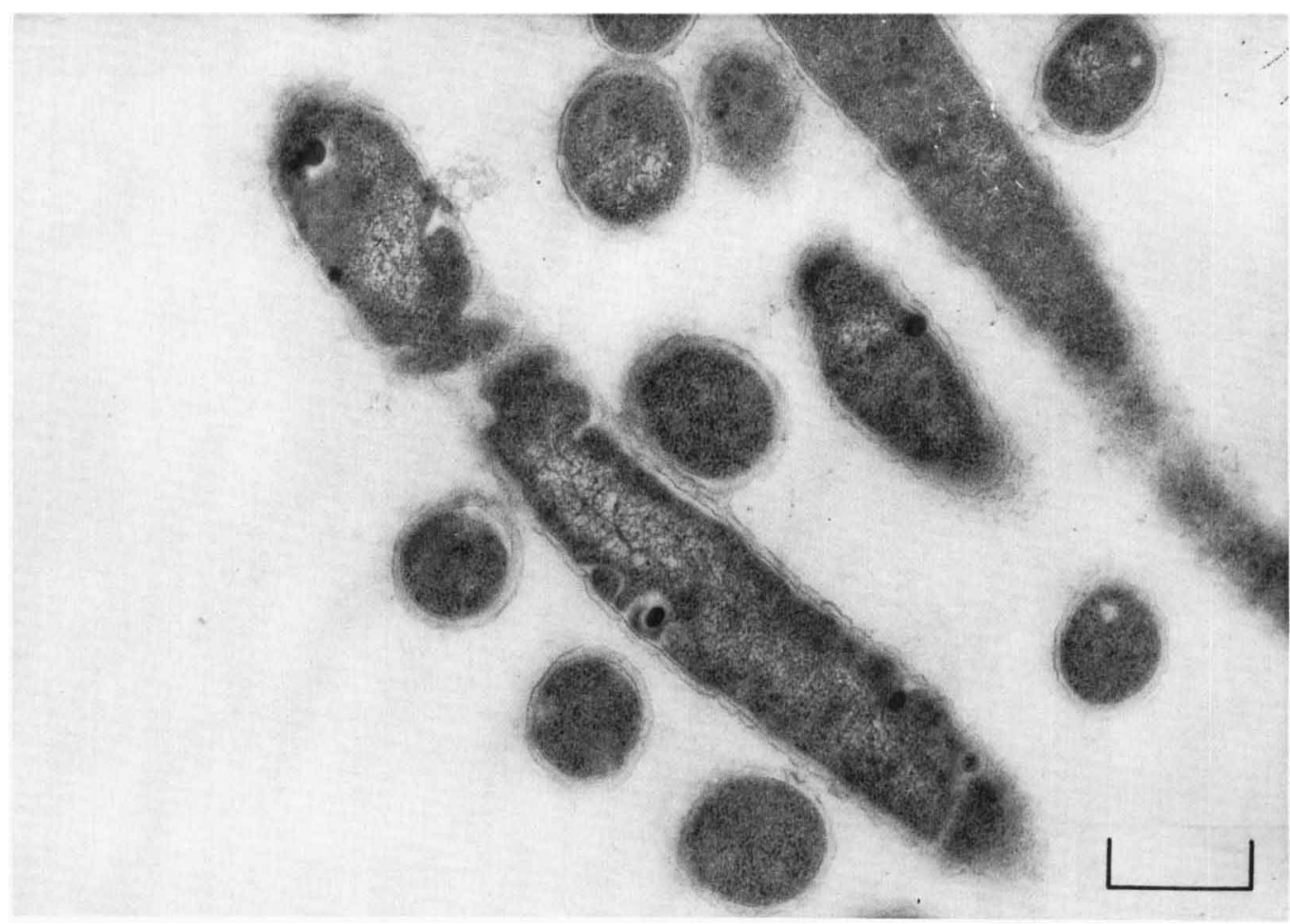

FIG. 3. Electron micrograph of an ultrathin section of strain HB8. The cells were fixed in osmium tetroxide, embedded in Epon, sectioned, and stained with lead citrate and uranyl acetate. The photograph was taken using a JEM $100 U$ electron microscope (Japan Electron Optics Laboratory Co., Ltd., Tokyo, Japan) at magnification of $\times 15,000$. The bar indicates $0.5 \mu \mathrm{m}$.

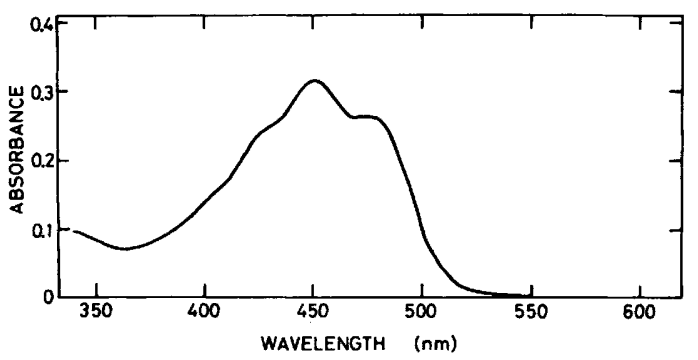

FIG. 4. Absorption spectrum of the pigments produced by strain $\mathrm{HB8}$. Cells $(0.15 \mathrm{~g}$ wet weight $)$ grown in polypeptone-yeast extract medium and washed with $0.8 \%$ sodium chloride solution were suspended in $3 \mathrm{ml}$ of $90 \%$ acetone $(\mathrm{vol} / \mathrm{vol})$. The absorption spectrum of the extract was recorded in a Beckman DK-IIA ratio recording spectrophotometer using a cuvette of 10-mm path length.

chloride, and no growth was observed in media containing $5 \%$ sodium chloride or more.

Practically no growth was observed in a synthetic medium containing glucose and ammonium salt as the carbon and nitrogen sources, respectively. Bovine serum albumin or milk casein could serve as the sole source of carbon and nitrogen, thus indicating that the present organism is proteolytic. Addition of a mixture of vitamins, growth factors, and minerals was necessary for good growth in an albumin or casein medium, but the minimum nutritional requirements of the organism have not yet been determined precisely.

Thermal properties. Most experiments on the growth of the isolate were carried out using an oil bath equipped with a reciprocal shaker (Taiyo Incubator M-III, Taiyo Kagaku Kogyo). Frequently the culture tube was covered with a polyester film to prevent loss of water by evaporation. HB8 is an obligate thermophile, since no growth was observed on incubation at $45 \mathrm{C}$ or less for a few days. The minimum temperature at which growth was detected within $48 \mathrm{~h}$ was $47 \mathrm{C}$, and growth was very poor below $50 \mathrm{C}$. The maximum temperature for growth was determined to be $85 \mathrm{C}$, although growth of the thermophile was slow and poor over $80 \mathrm{C}$. The effect of temperature on growth is shown in Fig. 5, and the optimum temperature was 65 to $72 \mathrm{C}$ under the conditions given in the legend to the figure. It was observed that the method and the rate of 
aeration greatly affected the growth rate. The generation time at the optimum temperature with vigorous shaking was 18 to $20 \mathrm{~min}$. A growth curve obtained at $75 \mathrm{C}$ is given in Fig. 6 . In the stationary phase, the cell density was $8 \times 10^{8}$ cells per ml (Fig. 6 ).

Strain HB8 is fairly resistant to heat treatment at $90 \mathrm{C}$. The half-time for death of cells heated in a Casamino Acids-yeast extract medium at $90 \mathrm{C}$ was $8 \mathrm{~min}$ (Fig. 7). No growth was observed at $90 \mathrm{C}$, but the thermophile seemed to be metabolically active at this temperature since acid was produced on addition of glucose to the suspension. Glucose was also metabolized by the organism at $45 \mathrm{C}$ or below, again judging by the production of acid. At $95 \mathrm{C}$, strain $\mathrm{HB} 8$ was killed rapidly, and only $1 \%$ of the cells survived after $15 \mathrm{~min}$.

Base composition of DNA. The base composition of the DNA of strain HB8 was determined by the method described above. The guanine plus cytosine content of the DNA was estimated to be $69 \%$ from paper chromatograms of the acid hydrolysate. No bases other than guanine, adenine, cytosine, and thymine were detected on the paper chromatograms. The results of this chemical analysis were in good accord with the estimated values from the melting temperature $(97.5 \mathrm{C})$ and from the

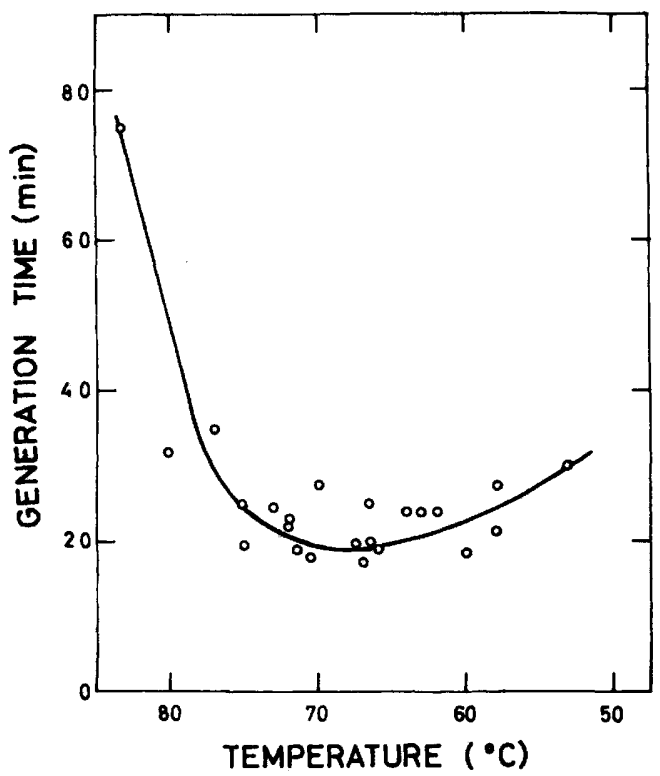

FIG. 5. Effect of temperature on the growth rate. The thermophile was grown in 200-ml Erlenmeyer flasks which contained $60 \mathrm{ml}$ of the Casamino Acids-yeast extract medium and which were covered with alminum caps. Flasks were reciprocally shaken at 130 strokes per min in an oil bath. Growth was followed by measuring the absorbancy at $600 \mathrm{~nm}$.

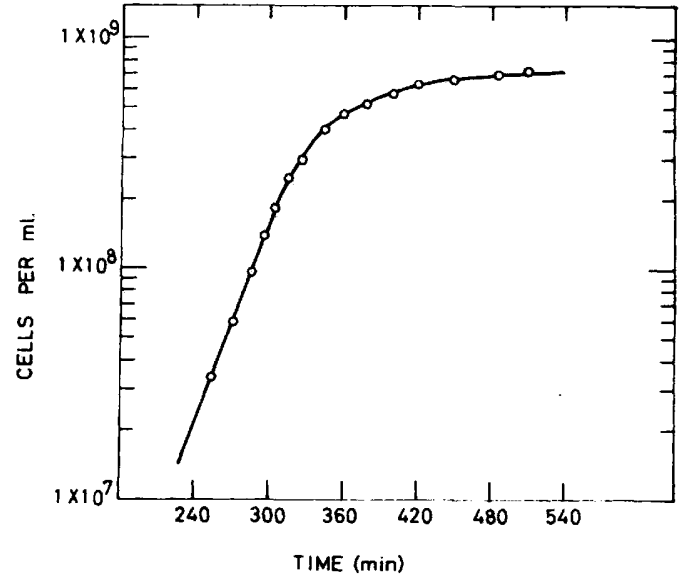

FIG. 6. Growth rate of strain $\mathrm{HB} 8$ at $75 \mathrm{C}$. The experimental conditions were as for Fig. 5, except that the temperature was fixed at $75 C$.

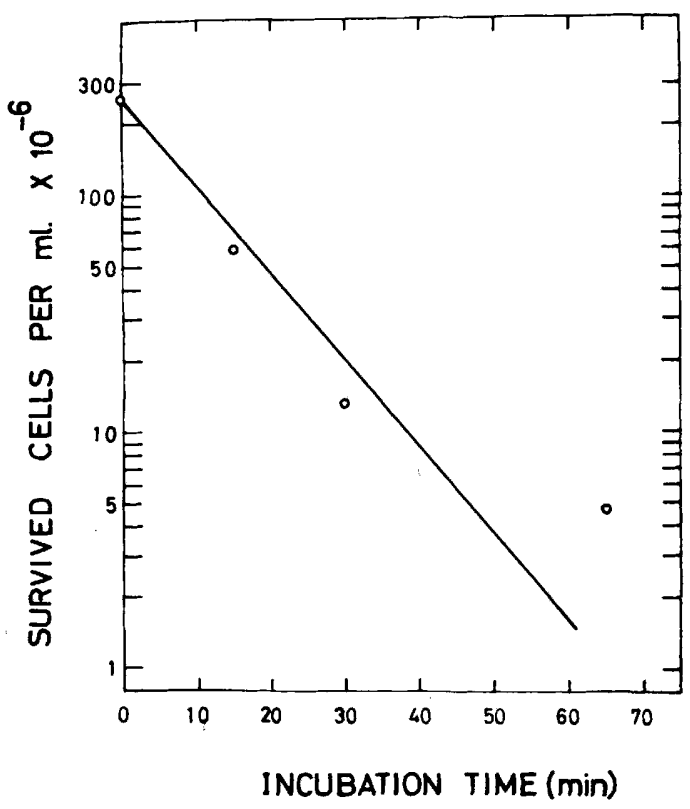

FIG. 7. Thermal killing curve. Cells of strain $H B 8$ in Casamino Acids-yeast extract medium were incubated in an oil bath at $90 \mathrm{C}$. At intervals, samples were taken and viable cells were counted on agar plates.

density in cesium chloride solution (1.727 $\left.\mathrm{g} / \mathrm{cm}^{3}\right)$. The details of the physicochemical properties of the DNA will be published elsewhere.

Effect of antibiotics. The effect of various antibacterial agents on the thermophile were investigated by adding suitable amounts of each antibiotic to cells in polypeptone-yeast extract medium. Strain HB8 was sensitive to various antibiotics. No growth was observed after $24 \mathrm{~h}$ of incubation at $75 \mathrm{C}$ when the following 
antibiotics were added individually to the polypeptone-yeast extract medium at a concentration of 8 to $10 \mu \mathrm{g} / \mathrm{ml}$ : penicillin, gramicidin $\mathrm{J}$, ampicillin, novobiocin, ristocetin, methicillin, streptomycin, and chloramphenicol. Actinomycin $D$ was also strongly inhibitory: at a concentration of $0.4 \mu \mathrm{g} / \mathrm{ml}$ it strongly repressed growth, and at a concentration of $1.0 \mu \mathrm{g} / \mathrm{ml}$ or more it inhibited growth completely. Tetracycline and D-cycloserine were only slightly inhibitory: at concentrations of $10 \mu \mathrm{g} / \mathrm{ml}$ they did not prevent growth, although at concentrations of $100 \mu \mathrm{g} / \mathrm{ml}$ they inhibited growth completely. Sodium dodecyl sulfate, sodium deoxycholate, and ethylenediaminetetraacetate (EDTA) were also effective inhibitors of strain HB8, preventing growth completely at concentrations of $0.5 \mathrm{mM}, 1 \mathrm{mM}$, and $0.5 \mathrm{mM}$, respectively. Growth was observed in the presence of $0.1 \mathrm{mM}$ sodium dodecyl sulfate and of EDTA.

Action of lysozyme. Cells of strain HB8 were attacked by egg-white lysozyme and converted to spherical, spheroplast-like bodies. However, for quantitative conversion to spherical bodies, a higher concentration of lysozyme and a higher temperature were required than for the preparation of $E$. coli spheroplasts. More than $80 \%$ of the cells were converted to a spherical form within $30 \mathrm{~min}$ when washed cells $(4 \mathrm{~g}$ wet weight) were suspended in $20 \mathrm{ml}$ of $0.1 \mathrm{M}$ sodium carbonate-sodium bicarbonate buffer (pH 9.7) containing $10 \mathrm{mg}$ of egg-white lysozyme (Grade I, Sigma Chemical Co., St. Louis, Mo.), 0.6 M sucrose, $0.05 \mathrm{M}$ sodium chloride, $0.05 \mathrm{M}$ potassium chloride, and 0.004
$M$ EDTA, and incubated at $60 \mathrm{C}$. The cells were fairly resistant to lysozyme at temperatures below $60 \mathrm{C}$.

In contrast to $E$. coli spheroplasts, the spheres thus formed were osmotically resistant and were fairly stable under hypotonic conditions. Lysis of the spherical bodies was followed by determining various enzymatic activities and proteins released into the medium. Table 1 shows the release of a glycolytic enzyme, phosphoglucomutase, and of materials with ultraviolet absorption into the medium under various conditions. The release of aldolase was parallel to that of phosphoglucomutase, whereas succinate dehydrogenase was bound to the membrane fractions and was not released into the medium. The results shown in Table 1 indicate that the rupture of spherical bodies was not completed after heating at $70 \mathrm{C}$ for $5 \mathrm{~min}$ or after incubation at $4 \mathrm{C}$ for $24 \mathrm{~h}$ in $0.05 \mathrm{M}$ Tris-hydrochloride buffer. Another experiment showed that rupture was not complete even in distilled water at a high temperature. Addition of magnesium salt seemed to stabilize the spheres. However, they lysed immediately upon addition of $0.5 \%$ Brij 58. The results given in Table 1 are quite consistent with observations made by phasecontrast microscopy.

Heat stability of bulk protein. To obtain a rough estimation of the thermal stability of the protein of the thermophile, the protein precipitated by heating the cell extract was estimated and compared with that of $E$. coli (strain B) protein. An extract of strain $\mathrm{HB} 8$ obtained by sonic treatment was diluted to a protein

TABLE 1. Stability of spherical bodies produced on treatment with lysozyme action

\begin{tabular}{|c|c|c|}
\hline Treatment $^{a}$ & $\begin{array}{l}\text { Phosphoglucomutase } \\
\text { in the supernatant } \\
(\mathrm{mU} / \mathrm{ml})\end{array}$ & $\begin{array}{l}\text { Absorbancy at } \\
280 \text { nm of the } \\
\text { supernatant }\end{array}$ \\
\hline 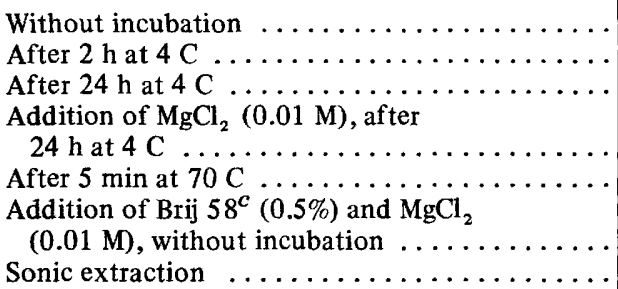 & $\begin{array}{r}8.1 \\
9.6 \\
10.1 \\
\\
5.2 \\
10.2 \\
\\
24.9 \\
19.2\end{array}$ & $\begin{array}{l}1.0 \\
1.0 \\
1.0 \\
1.0 \\
1.8 \\
2.4 \\
3.4\end{array}$ \\
\hline
\end{tabular}

\footnotetext{
${ }^{a}$ Spherical bodies formed by treating the intact cells with egg-white lysozyme were washed once with $0.1 \mathrm{M}$ carbonate buffer ( $\mathrm{pH} 9.6$ ) containing $0.6 \mathrm{M}$ sucrose. The washed sphericals obtained from $0.67 \mathrm{~g}$ of wet cells were suspended in $5 \mathrm{ml}$ of chilled buffer $(0.05 \mathrm{M}$ Tris-hydrochloride, $\mathrm{pH} 7.5)$. After incubation as indicated, the suspensions were centrifuged at $10,500 \times \mathrm{g}$ for $30 \mathrm{~min}$, and the enzyme activity and absorbancy at $280 \mathrm{~nm}$ of the supernatants were measured.

$b$ Enzyme activity was assayed at $30 \mathrm{C}$ as reported previously (25).

${ }^{c}$ Product of Kao-Atlas Co., Ltd., Tokyo. Addition of Brij 58 did not affect phosphoglucomutase activity.
} 
concentration of $11 \mathrm{mg} / \mathrm{ml}$ with $0.05 \mathrm{M}$ Tris-hydrochloride buffer, $\mathrm{pH} 7.5$. Samples of the extract were heated at various temperatures for $5 \mathrm{~min}$, and the precipitate of denatured protein was determined as described above.

A plot of percentage of the denatured protein versus the heating temperature is given in Fig. 8. For a comparison, an extract of $E$. coli $(11 \mathrm{mg}$ of protein per $\mathrm{ml}$ ) was treated in the same manner, and the results are also given in the figure. No precipitate was formed when the extract of the thermophile was heated up to $80 \mathrm{C}$ and most of the protein in the extract was stable on heat treatment at $100 \mathrm{C}$ for $5 \mathrm{~min}$. Only $10 \%$ of the total protein extracted was precipitated on heating at $110 \mathrm{C}$. In contrast, $75 \%$ of the bulk protein in the cell-free extract of $E$. coli was denatured, and most of it was precipitated on heating at $70 \mathrm{C}$ for $5 \mathrm{~min}$. On this basis, the protein of the thermophile is much more heat stable than that of the mesophile.

Samejima and Takamiya (17) studied the heat stability of the protein of $B$. stearothermophilus and found that the protein of this moderate thermophile is more stable than those of such mesophiles as $B$. subtilis and $B$. megaterium. From the data reported by these authors, it is obvious that the protein of the presently described extreme thermophile is more heat stable than that of the moderate thermophile.

Amino acid composition of the bulk protein. The amino acid composition of the bulk protein in the cell-free extract of the thermophile was analyzed and compared with that of $E$. coli. The results are shown schematically in Fig. 9. The amino acid composition of the protein of $E$. coli shown in the figure is in good accord with that reported in the literature (18).

\section{DISCUSSION}

The thermophile reported here is a yellowpigmented, nonmotile, gram-negative rod. These morphological features are similar to those reported for strains of Flavobacterium (2), but the thermophile has a growth temperature different from that of flavobacteria. The guanine plus cytosine content of the DNA of this thermophile was determined to be $69 \mathrm{~mol}$ $\%$, which is close to the values reported for DNA from some organisms in the genus Flavobacterium, such as $F$. esteroaromaticum, $F$. suaveolens, $F$. arborescens, and $F$. flavescens; however, the type species, $F$. aquatile, has a guanine plus cytosine value of 32 to $34 \mathrm{~mol} \mathrm{\%}$

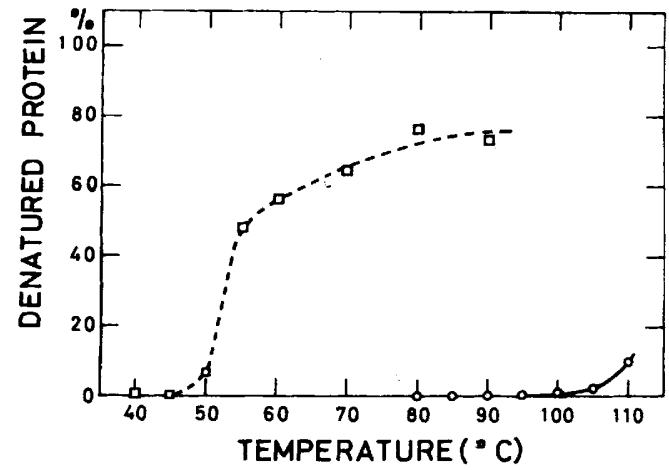

FIG. 8. Heat stabilities of the bulk proteins of $T$. thermophilus and E. coli. Sonic extracts $111 \mathrm{mg}$ of protein per $\mathrm{ml}$ ) were incubated at the indicated temperatures for 5 min. After rapid cooling, the precipitated protein was collected and estimated with phenol reagent. Symbols: - $-T$. thermophilus protein; -...., E. coli protein.

(19). Initially the thermophilic isolate was tentatively named Flavobacterium thermophilum $(15,24,25)$; subsequently Yoshida and Oshima (23) definitely proposed the name Flavobacterium thermophilum for this organism. However, Flavobacterium is a poorly defined genus $(5,21)$, and even though the presently described thermophile could be assigned to it because of general similarities, there is no real taxonomic basis for this. Extended studies of this organism as reported here suggest that it belongs to the genus Thermus, and in our opinion it is sufficiently different from $T$. aquaticus to be considered a separate species. For these reasons, the authors propose the transfer of this organism to the genus Thermus as Thermus thermophilus (Yoshida and Oshima) comb. nov. The type strain of this species is HB8 (=ATCC 27634). Because the description of the species is based on a single isolate, the species description given here also serves as the description of the type strain.

The properties of $T$. thermophilus HB8 are similar to those of the type strain of $T$. aquaticus, YT-1 (=ATCC 25104) (5). The cells of both strains are gram-negative, yellowpigmented, nonsporulating rods. Moreover, the absorption spectrum of the pigment(s) in the latter (9) resembles that of strain $\mathrm{HB} 8$, as shown in Fig. 4. The base composition of $T$. aquaticus DNA is similar to that of the DNA of $T$. thermophilus. Although $T$. thermophilus HB8 is gram negative, it is highly sensitive to antibiotics such as actinomycin $\mathrm{D}$, novobiocin, and methicillin, which are known to be rather ineffective against other gram-negative bacteria. Similarly, $T$. aquaticus is sensitive to low 


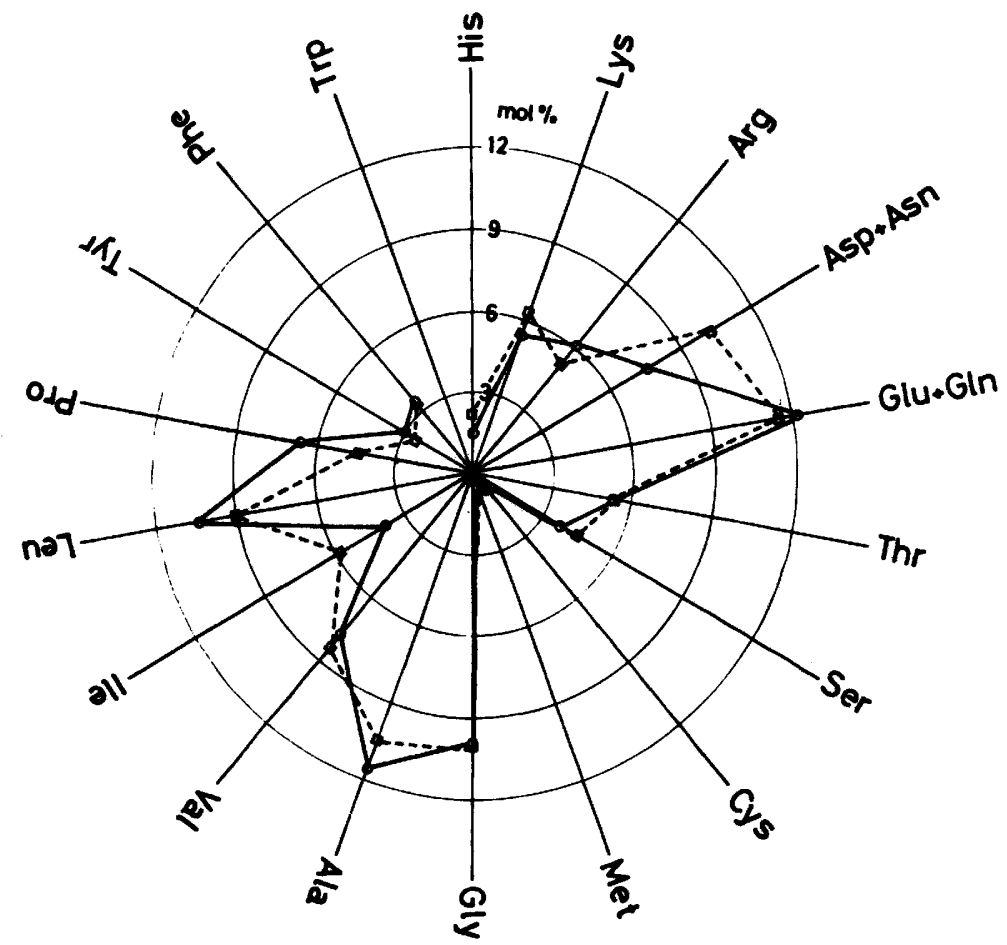

FIG. 9. Comparison of the amino acid compositions of proteins of T. thermophilus and E. coli. Contents of amino acid are expressed as molar proportions of the total amount recorded in an amino acid analyzer. Tryptophan was not analyzed. Symbols:,$- T$. thermophilus protein; $\cdots \cdots, E$. coli protein.

concentrations of actinomycin $\mathrm{D}$, novobiocin, and penicillin. The enzymes of $T$. thermophilus HB8 thus far investigated are all heat resistant (23-25). For example, more than $80 \%$ of the phosphofructokinase activity remained after heating the enzyme preparation at $80 \mathrm{C}$ for $7 \mathrm{~h}$. Freeze and Brock (8) reported that the aldolase of $T$. aquaticus is quite stable at $97 \mathrm{C}$. The aldolase of strain HB8 was also heat stable, though a little less stable than that of $T$. aquaticus since a purified preparation lost $60 \%$ of its activity on heating at $95 \mathrm{C}$ for $5 \mathrm{~min}$ (unpublished data). The thermal properties of the transfer ribonucleic acid and ribosomes of $T$. thermophilus (15) are strikingly similar to those of $T$. aquaticus (26). Nevertheless, the former differs from the latter in the following features. (i) Morphologically, T. aquaticus has a long filamentous form unlike our thermophile. The formation of large spherical bodies in older cultures has also been reported as a distinctive characteristic of $T$. aquaticus, but no such bodies were seen in cultures of $T$. thermophilus. In older cultures, cells of strain HB8 aggregated to form linear arrays or rosettes, as reported for $T$. aquaticus, but they did not form large spherical bodies. (ii) T. aquaticus grew well in a synthetic medium containing glutamate as the sole carbon and nitrogen source but did not grow in a medium containing tryptone plus yeast extract at a concentration of $1 \%$ or more. In contrast, our thermophile did not grow well in synthetic media but did grow well in a medium containing $2 \%$ polypeptone plus $1 \%$ yeast extract. Moreover, our organism could grow in a medium containing $2 \%$ sodium chloride whereas $T$. aquaticus could not. (iii) The maximum temperature for growth of strain HB8 was a little higher than that of $T$. aquaticus, and its generation time was shorter. (iv) Our thermophile was resistant to lysozyme at room temperature. In the case of $T$. aquaticus, the formation of spheroplasts by the use of lysozyme has been reported (5), but the necessity of incubation at higher temperatures for the lysozyme action has not been described.

The cell envelopes of strain HB8 show some distinctive characteristics: the mesosomes seen in the electron micrographs suggest that the membrane system is very complex (mesosomes have also been observed in the membrane of the moderate thermophile, B. stearothermophilus [20]); the cells were resistant to egg-white lysozyme at room temperature; and the sphero- 
plast-like bodies produced by treatment with lysozyme at $60 \mathrm{C}$ were resistant to both heat and osmotic shock (the spheroplasts of $T$. aquaticus and $B$. stearothermophilus have also been reported to be highly stable under hypotonic conditions $[1,4])$. These observations, together with those reported for the thermophiles $B$. stearothermophilus and $T$. aquaticus, support the proposition that the integrity of the cell membranes may be closely correlated to the heat resistance of the organism $(3,4)$. In this context, $M$. Oshima (personal communication) analyzed the lipid composition of strain HB8 and detected an unknown glycolipid and an unknown phospholipid as major components. These unidentified lipids constituted more than two-thirds of the total lipid content by weight. The glycolipid consisted of one residue each of glucose, $N$-15-methylhexadecanoylglucosamine, and diglyceride, and two residues of galactose (14). Determination of the chemical structures of these new lipids of the membrane of $T$. thermophilus strain HB8 may contribute to elucidation of the unusual stability of the membrane to heat and osmotic shock.

Sueoka $(18,19)$ reported several slight, but significant, correlations between the amino acid composition of bulk protein and the base composition of DNA. The contents of alanine, proline, glycine, and arginine are positively correlated with the guanine plus cytosine content of the DNA, whereas those of aspartic acid, isoleucine, and some other amino acids are negatively correlated with the guanine plus cytosine content of the DNA. The amino acid composition of the bulk protein and the base composition of the DNA of strain HB8 were consistent with the reported correlations. The molar proportions of arginine, alanine, leucine, and proline are higher in the proteins of this strain than in those of $E$. coli (Fig. 9). However, the molar contents of individual amino acids of strain HB8 differed only slightly from those of the bulk protein of $E$. coli, although the thermophile proteins were much more resistant to heat than those of the mesophile, as shown in Fig. 8. The results of amino acid analyses do not provide any clue to the reason for the thermostability of the thermophile's proteins. High heat stability could be due to the presence of $S-S$ linkages, but the proteins of the thermophile did not seem to contain large numbers of $S-S$ bonds since the cysteine content was lower than that of $E$. coli proteins. A hydrophobic interaction might be responsible for the increased stability of $T$. thermophilus proteins, but there is no evidence for this, and the total molar proportion of hydrophobic amino acids (left half of Fig. 9) of the thermophile's protein is a little less than that of $E$. coli. However, these data do not disprove this possibility. Detailed studies on the individual proteins of the thermophile, including their-amino acid sequences and three-dimensional structures, will be necessary to elucidate the molecular basis of their thermal stability.

\section{ACKNOWLEDGMENTS}

We are grateful to Akira Matsuda and Takeshi Tanaka of the Research Laboratories, Pharmaceutical Division, Nippon Kayaku Co. Ltd., Tokyo, Japan, for making the ultrathin sections and electron micrographs shown in Fig. 3. We are also indebted to S. Toriyama of the Faculty of Agriculture, University of Tokyo, for his help in taking an electron micrograph (Fig. 2).

\section{REPRINT REQUESTS}

Address reprint requests to: Dr. Tairo Oshima, Mitsubishi-Kasei Institute of Life Sciences, Minamiooya, Machida, Tokyo 194, Japan.

\section{LITERATURE CITED}

1. Bodman, H., and N. E. Welker. 1969. Isolation of spheroplast membranes and stability of spheroplasts of Bacillus stearothermophilus. J. Bacteriol. 97:924-935.

2. Breed, R. S., E. G. D. Murray, and N. R. Smith (ed.). 1957. Bergey's manual of determinative bacteriology, 7 th ed. The Williams \& Wilkins Co., Baltimore.

3. Brock, T. D. 1967. Life at high temperatures. Science 158:1012-1019.

4. Brock, T. D. 1969. Microbial growth under extreme conditions, p. 15-41. In P. M. Meadow and S. J. Pirt (ed.), Microbial growth. Cambridge Univ. Press, London.

5. Brock, T. D., and H. Freeze. 1969. Thermus aquaticus gen. n. and sp. n., a nonsporulating extreme thermophile. J. Bacteriol. 98:289-297.

6. Crestfield, A. M., S. Moore, and W. H. Stein. 1963. The preparation and enzymatic hydrolysis of reduced and S-carboxymethylated proteins. J. Biol. Chem. 238:622-627.

7. Emoto, Y. 1965. List of biological entities inhabiting thermal springs in Japan. IV. Thermal flora of Japan. J. Soc. Eng. Mineral Springs, Japan. 3:1 73-1 82.

8. Freeze, H., and T. D. Brock. 1970. Thermostable aldolase from Thermus aquaticus. J. Bacteriol. 101:541-550.

9. Heinen, U. S., G. Klein, H. P. Klein, and W. Heinen. 1971. Comparative studies on the nature and distribution of pigments from two thermophilic bacteria. Arch. Mikrobiol. 76:18-27. 
10. Kalckar, H. M. 1947. Differential spectrophotometry of purine compounds by means of specific enzymes. III. Studies of the enzymes of purine metabolism. J. Biol. Chem. 167:461-475.

11. Lowry, O. H., N. J. Rosebrough, A. L. Farr, and R. J. Randall. 1951. Protein measurement with the Folin phenol reagent. J. Biol. Chem. 193:265-275.

12. Marmur, J. 1961. A procedure for the isolation of deoxyribonucleic acid from micro-organisms. J. Mol. Biol. 3:208-218.

13. Marshak, A., and H. J. Vogel. 1951. Microdetermination of purines and pyrimidines in biological materials. J. Biol. Chem. 189:597-605.

14. Oshima, M. 1972. Isolation and partial characterization of novel glycolipid from an extremely thermophilic bacterium. Biochem. Biophys. Res. Commun. 49:185-191.

15. Oshima, T., and K. Imahori. 1971. Isolation of an extreme thermophile and thermostabilities of its transfer ribonucleic acid and ribosomes. J. Gen. Appl. Microbiol. 17:513-517.

16. Saito, H., and K. Miura. 1963. Preparation of transforming deoxyribonucleic acid by phenol treatment. Biochim. Biophys. Acta 72:619-629.

17. Samejima, T., and A. Takamiya. 1958. Comparative studies on heat stability of proteins of thermophilic and mesophilic bacteria. Cytologia 23:509-519.

18. Sueoka, N. 1961. Correlation between base composition of deoxyribonucleic acid and amino acid composition of protein. Proc. Nat. Acad. Sci. U.S.A. 47:1141-1149.
19. Sueoka, N. 1964. Compositional variation and heterogeneity of nucleic acids and protein in bacteria, p. 419-443. In I. C. Gunsalus and R. Y. Stanier (ed.), The bacteria, vol. 5. Academic Press Inc., New York.

20. Walker, P. D., and A. Baillie. 1968. Structure of Bacillus stearothermophilus: an electron microscope study. J. Appl. Bacteriol. 31:108-113.

21. Weeks, O. B. 1969. Problems concerning the relationships of cytophages and flavobacteria. J. Appl. Bacteriol. 32:13-18.

22. Wyatt, G. R. 1955. Separation of nucleic acid components by chromatography on filter paper, p. 243-265. In E. Chargaff and J. N. Davidson (ed.), The nucleic acids, vol. 1. Academic Press Inc., New York.

23. Yoshida, M., and T. Oshima. 1971. The thermostable allosteric nature of fructose 1,6-diphosphatase from an extreme thermophile. Biochem. Biophys. Res. Commun. 45:495-500.

24. Yoshida, M., T. Oshima, and K. Imahori. 1971. The thermostable allosteric enzyme: phosphofructokinase from an extreme thermophile. Biochem. Biophys. Res. Commun. 43:36-39.

25. Yoshizaki, F., T. Oshima, and K. Imahori. 1971. Studies on phosphoglucomutase from an extreme thermophile, Flavobacterium thermophilum HB8. I. Thermostability and other enzymatic properties. J. Biochem. 69:1083-1089.

26. Zeikus, J. G., M. W. Taylor, and T. D. Brock. 1970. Thermal stability of ribosomes and RNA from Thermus aquaticus. Biochim. Biophys. Acta 204:512-520. 